\title{
The Vertical and Horizontal Distribution of Sea Scallop (Placopecten magellanicus) Larvae in the Bay of Fundy in 1984 and 1985
}

\author{
M. J. Tremblay and M. M. Sinclair \\ Department of Fisheries and Oceans \\ Biological Sciences Branch, P. O. Box 550 \\ Halifax, Nova Scotia, Canada B3J 257
}

\begin{abstract}
The vertical and horizontal distributions of sea scallop larvae (Placopecten magellanicus) in the Bay of Fundy were surveyed during September, October, and November of 1984 and during October of 1985. Larvae were distributed throughout the water column, although at some locations pronounced peaks in concentration associated with the thermocline occurred at depths between 5 and $20 \mathrm{~m}$. Vertical stratification by size occurred, but was not consistent between stations. The horizontal distribution of larvae was compared with the distribution of commercial sea scallops (potential spawners) and the residual circulation pattern. Mean larval number per $\mathrm{m}^{2}$ was usually highest in the Outer Bay, where the greatest biomass of potential spawners was found. Some transport of larvae in the direction of the residual currents is indicated by changes in length frequency distribution. Sea scallop larvae found in the Bay of Fundy appear to originate there, rather than from the Gulf of Maine, or the Scotian Shelf.
\end{abstract}

\section{Introduction}

Major commercial concentrations of sea scallops are found in the Bay of Fundy, on the Scotian Shelf and on Georges Bank (Fig. 1). Although the aggregations are persistent, recruitment to each area fluctuates greatly from year to year (Sinclair et al., 1985). Fundamental questions which need to be addressed are the causes of these fluctuations, and the geographic source of recruitment. Events during the larval stage may be critical to the level of recruitment to the Bay of Fundy scallop fishery 5 to 6 years later (Dickie, 1955; Caddy, 1979).

The only published account of larval sea scallop distribution for any location is a short communication dealing with bivalve larval abundance in the nearshore region of the Gulf of Maine off New Hampshire, USA (Savage, 1980). Serchuk et al. (1979) (citing Bourne, 1964) stated that $P$. magellanicus larvae had never been positively identified in plankton collections. By examining larval hinge structure, the routine identification of larval sea scallops from the plankton is now possible (Tremblay et al., 1987).

The distribution of sea scallop larvae has been assumed to be a simple function of surface current direction and speed (Posgay 1979, Serchuk et al., 1979). Posgay (1979) stated 'During the month or more that the eggs and larvae are planktonic, they are trans- ported long distances in the prevailing surface currents. No local aggregation can be self-reproducing, with the possible exception of Georges Bank, where a semipersistent gyre may retain the spawning products

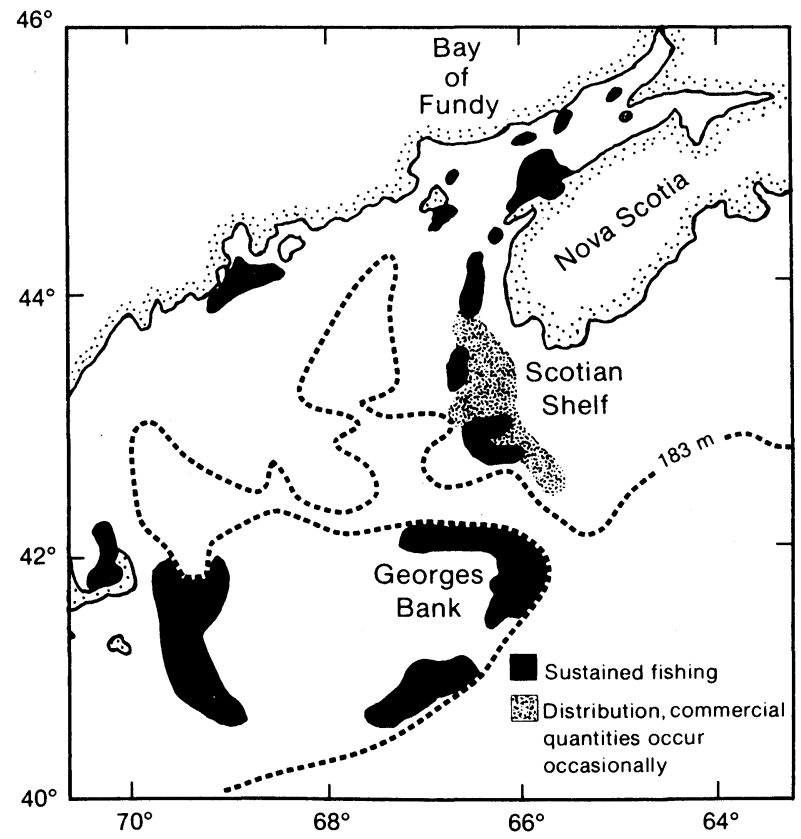

Fig. 1. The distribution of sea scallop fishing areas in the Bay of Fundy-Gulf of Maine region (modified from Sinclair et al., 1985). 
long enough for them to complete development and settle out'. An assumption of this view is that sea scallop larvae are distributed in the surface layer, which is generally considered to be above the thermocline, where wind drift can have an effect. In the Gulf of Maine area this corresponds to the upper 10 to $25 \mathrm{~m}$.

One of the objectives of the present paper is to evaluate the assumption of surface layer distribution of sea scallop larvae in the Bay of Fundy. The second objective is to compare our measurements of larval abundance and length frequency with that expected from knowledge of the source of scallop larvae, and the prevailing residual circulation, in order to evaluate the geographic source of larvae observed in the Bay of Fundy.

The generalized residual circulation in the Bay of Fundy is counter-clockwise, with a gyre present in the Outer Bay (Fig. 2). Greenberg (1983) noted that Godin's (1968) analysis of Bay of Fundy current meter data showed variability in the Bay of Fundy gyre, and strong eddies in the Inner Bay near Cape Split. Tee (1977) also found eddies near Cape Split. Examination of bottom drifter returns in the Bay of Fundy suggest that the counter-clockwise circulation is confined to the outer half of the Bay (Lauzier, 1967).

If larval scallop distribution in the Bay of Fundy is a function of current direction and speed, some percentage of larvae spawned in the Outer Bay of Fundy should be transported up the Bay on the Nova Scotia side, to be either trapped in the extreme Inner Bay or to be transported back out the Bay along the New Brunswick side. Since residual current speeds in the upper $15 \mathrm{~m}$ of the Bay of Fundy are approximately 22 to $44 \mathrm{~km}$

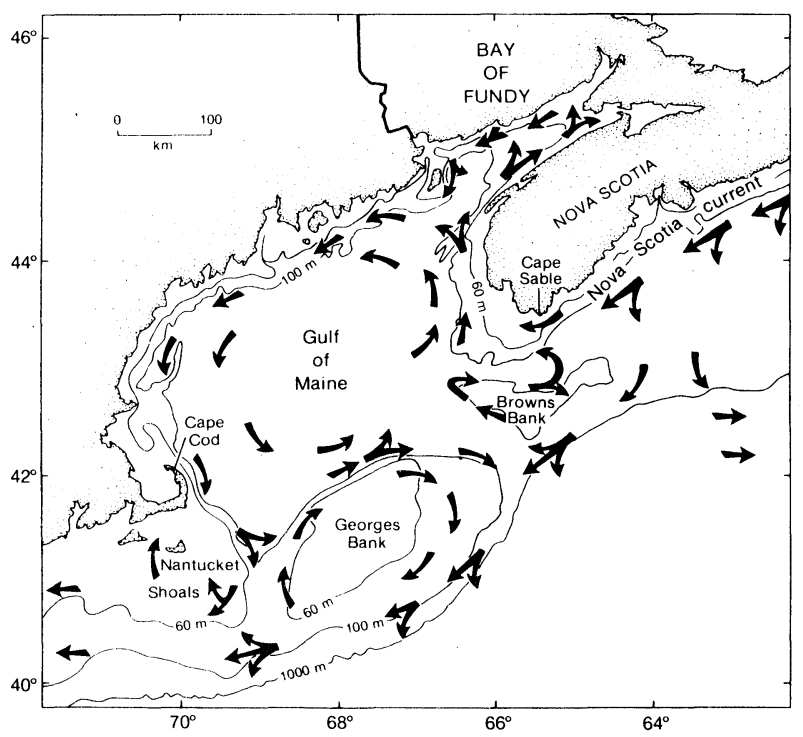

Fig. 2. Residual circulation of the Gulf of Maine region (as drawn by R. Trites, Bedford Institute of Oceanography, Dartmouth, Nova Scotia). per day (Godin, 1968), larvae could be transported the length of the Bay of Fundy in 3 to 6 days. This should be reflected in the larval abundance and length frequency data by (i) greater numbers of larvae in the Inner Bay than expected from the spawning biomass present there and (ii) a gradient in larval length in the direction of the counter-clockwise circulation.

On the shelf region off Southwest Nova Scotia, residual currents move in the direction of the Bay of Fundy, at speeds of approximately $3.4-8.6 \mathrm{~km}$ per day (Smith, 1983). If larval distribution is a function of this circulation, larvae should be transported into the Bay of Fundy in a few weeks. Laboratory studies (Culliney, 1974; Couturier, 1986) indicate that the larval period is usually 30-60 days. Therefore, if larvae drift passively in the surface layer, dispersal on the scale of 100 s of kilometers is possible.

\section{Methods}

\section{Sample collection and processing}

Scallop larvae were collected in the Bay of Fundy during three periods in 1984 (6-13 September, 10-15 October and 3-14 November) and from 1 to 6 October 1985 (Fig. 3). Most scallop spawning occurs in the Bay of Fundy between August and October (Dickie, 1955; Robert and Lundy, MS 1985). Larvae were also collected on the Scotian Shelf, the Gulf of Maine and

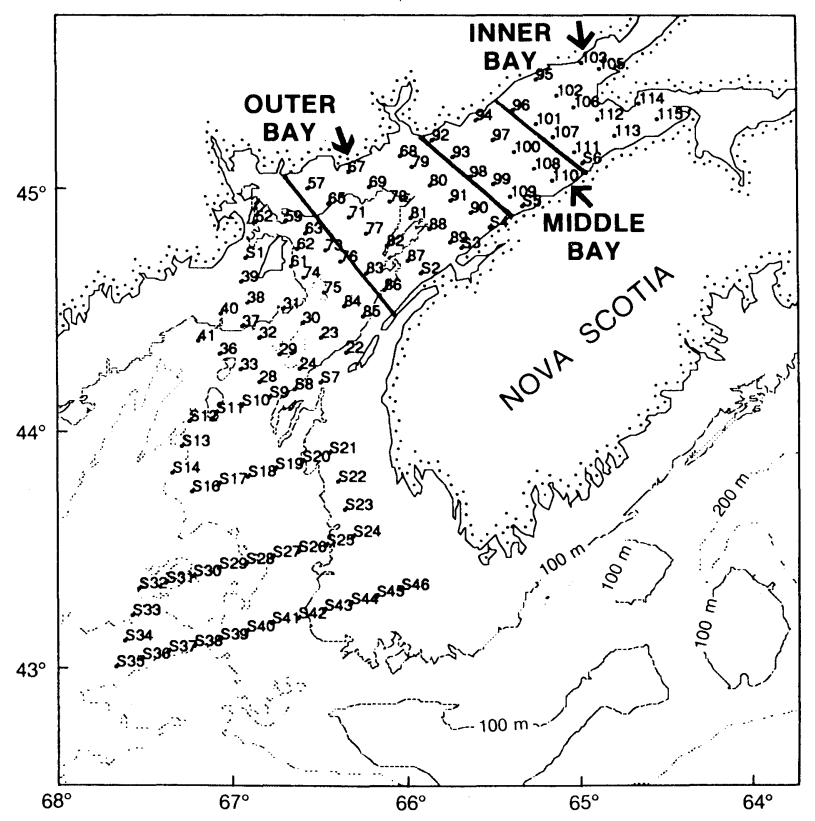

Fig. 3. Stations sampled for larval sea scallops during at least one of the following periods: 6-13 September, 10-15 October, 3-14 November 1984, and 1-11 October 1985. Also depicted are the Outer, Middle and Inner Bay areas, for which adult scallop catch statistics, and larval numbers and length were compiled. 
Georges Bank during 6-11 October 1985, however, only stations in the Bay of Fundy, its upstream approaches and part of the Scotian Shelf (Fig. 3) are considered in this paper.

The horizontal distribution of larvae was surveyed on a $24 \mathrm{hr}$ basis with plankton nets mounted on a bongo frame and fitted with Tsurumi-Seiki (TSK) flowmeters. The plankton nets were modified versions of the WP-2 type (Be et al., 1968) and had a filtration ratio (open area: mouth area) of 5:1. In 1984 the bongo frames were $50 \mathrm{~cm}$ in diameter and were fitted with $120 \mu \mathrm{m}$ mesh. In 1985 the mouth diameter was reduced to $40 \mathrm{~cm}$ and the mesh size was decreased to $85 \mu \mathrm{m}$. These modifications were made to decrease the volume sampled and to better sample the smallest scallop larvae.

The ship remained as stationary as possible during the 5 to $15 \mathrm{~min}$ it took to complete the sampling at any one station. The bongo frame with nets was lowered to within $5 \mathrm{~m}$ of the bottom (or to $200 \mathrm{~m}$ ) and towed to the surface at a speed of approximately $40 \mathrm{~m}$ per minute. The mean volume of water sampled per plankton tow was less than $32 \mathrm{~m}^{3}$, with the range of volumes sampled ( 3 to $109 \mathrm{~m}^{3}$ ) reflecting the station depth and the angle of the wire towing the net.

The vertical distribution of sea scallop larvae was studied at selected stations in 1984 using a pump system, which delivered 350 to 450 litres per minute. The pump system consisted of a FLYGT model 2051 electric pump (impeller type) with a tandem coupling, $2.5 \mathrm{~cm}$ PVC suction hose, and a SIGNET in-line paddlewheel flowsensor and readout.

The ship drifted during sampling but because each station took 1.5 to $2.5 \mathrm{hr}$ to complete, drift from the original location could be up to 9 nautical miles (anchoring was not an option due to the effects of high tidal currents on gear deployment). The FLYGT pump was deployed 1 to $1.5 \mathrm{~m}$ below the surface, with a long length of hose (approximately $50 \mathrm{~m}$ to sample a $40 \mathrm{~m}$ depth) attached to the suction side and a short length on the delivery side leading to the ships deck. During sample collection, the intake end of the hose was attached to the end of a wire and moved slowly up and down within the following depth intervals: 0.5 to $5 \mathrm{~m} ; 6$ to $10 \mathrm{~m} ; 11$ to $20 \mathrm{~m} ; 21$ to $40 \mathrm{~m}$. Two samples were taken within each depth interval.

On deck, the water was passed through two NITEX nets suspended in a 160 litre drum. The first net $(333 \mu \mathrm{m}$ mesh) removed larger zooplankters; the second net (64 $\mu \mathrm{m}$ mesh) retained scallop larvae. Repetitive evaluation of the contents of the $333 \mu \mathrm{m}$ net samples indicated no scallop larvae were retained. Within the collection drum, the nets were submerged and the incoming water was not forced directly over the mesh, thus scallop larvae were collected in good condition. At all pump stations temperature profiles were obtained using expendable bathythermographs (XBTs).

To determine the abundance and length frequency of scallop larvae close to the seabed, an epibenthic sled was utilized in 1985. The sled was a modified version of the Macer-GIROQ model (Brunel et al., 1978) optimized for hard bottom sampling. It had two $85 \mu \mathrm{m}$ mesh plankton nets, $55 \mathrm{~cm}$ wide at the mouth, mounted 33 to $73 \mathrm{~cm}$, and 109 to $149 \mathrm{~cm}$ above the seabed. The sled was towed at a speed of 2.5 to 3 knots for 4 min. Unfortunately the sled could only be used sparingly due to time constraints and net damage. Although net tears prevented accurate determination of larval concentrations, the samples were used to indicate the length frequency of larvae close to the bottom.

Sea scallop larvae from all sampling methods were preserved in $4 \%$ formalin in seawater buffered with sodium borate. The physical separation and taxonomic identification of the scallop larvae is described in Tremblay et al. (1987). Length was measured as the greatest dimension parallel to the hinge.

\section{Data analysis}

For each bongo sample, the flowmeter reading, tow duration and mouth area of the net were used to calculate total volume sampled by the net. Larval counts were then converted to a number per $\mathrm{m}^{2}$ basis as follows:

$\mathrm{N}$ per $\mathrm{m}^{2}=\left(\right.$ Count/volume in $\left.\mathrm{m}^{3}\right) \times$ station depth $(\mathrm{m})$

Generally the larvae from only one of the bongo nets were sorted; where both samples were done, they were combined for the purposes of analysis. Larval counts from the pump samples were converted to numbers per $\mathrm{m}^{3}$ using the volume measured by the in line flowsensor.

Where parametric statistics were used, the assumptions were verified. The assumption of equal variance was checked using Bartlett's test; that of normality using the Kolmogorov - Smirnov test. Violations of both assumptions were evident, but for the abundance data, the following transformation usually made the assumptions valid:

$$
y=\log _{10}\left(\mathrm{~nm}^{-2}+1\right)
$$

In cases where this transformation was not effective, nonparametric methods were employed. For statistical comparisons of length, non-parametric methods were used exclusively because of the presence of more than one length mode in many of the larval samples.

\section{Larval distribution versus parental stock distribution}

The potential source of scallop larvae in the areas sampled is depicted in a generalized manner in Fig. 1. In addition, for the Bay of Fundy itself we utilized the 
1984 and 1985 data from fishing logs to obtain a more accurate representation of the parental stock distribution. The 'Class 1 data' utilized represents most of the fishing effort in the Bay of Fundy during 1984-85, and differs from landing statistics in that location and effort for the catch are known, rather than just the port where the catch was landed (G. Robert, Biological Sciences Branch, Halifax, Nova Scotia, pers. comm.). In using fishing catch data as an index of parental stock distribution, we assume that all significant sources of scallops are exploited, which is reasonable for this fishery.

Scallop landings were summed for three main Bay of Fundy areas: Outer, Middle and Inner (Fig. 3 and Table 1). Most of the landings originated in the Outer Bay; landings from the Inner Bay comprised only 2-3\% of the total in both years.

For the larval data only, the Middle and Inner areas were further divided into Nova Scotia and New Brunswick sides, to better reflect the circulation pattern within the Bay. The Outer Bay area was not subdivided since it encompasses a large gyre.

\section{Results}

\section{Vertical distribution}

Sea scallop larvae were present throughout the water column, with the degree of aggregation within any depth interval differing substantially between stations (Fig. 4). There was a positive relationship between the degree of temperature stratification and the extent to which larvae were aggregated over the upper $40 \mathrm{~m}$ (Fig. 5). In September, stations 78 and 80 had welldeveloped to moderate thermoclines, and the larvae appeared to be associated with them. Station 111 (the only Inner Bay station where larvae were abundant enough to sample) was well mixed, and larvae were distributed almost equally over the upper $40 \mathrm{~m}$.

In October the relationship between thermocline intensity and aggregation was less clear, with station 78 showing a large degree of larval aggregation in spite of the isothermal water column at that location (Fig. 4 and 5). Station 80 , with a slight thermocline, showed slight differences in larval concentration with depth. At sta-

TABLE 1. Commercial catch (in kilograms of meat) of sea scallops from Outer, Middle, and Inner Bay of Fundy areas in 1984 and 1985 (see Fig. 3 for area locations). Catch data is from fishing logs and represents a large subset of that given in Robert et al. (1986). Within year percentages of total catch are displayed in parentheses.

\begin{tabular}{lrrrr}
\hline \multicolumn{1}{c}{ Area } & \multicolumn{2}{c}{1984} & \multicolumn{2}{c}{1985} \\
\hline Outer Bay & 421,955 & $(78.0 \%)$ & 419,915 & $(90.4 \%)$ \\
Middle Bay & 102,236 & $(18.9 \%)$ & 34,971 & $(7.5 \%)$ \\
Inner Bay & 16,620 & $(3.1 \%)$ & 9,737 & $(2.1 \%)$ \\
\hline
\end{tabular}

tion 111 , the pattern of vertical distribution was very similar to September, even though a slight thermocline was present.

Length differences with depth were present, but inconsistent. The greatest difference was observed at station 78 in September, when larger larvae were observed in the upper $5 \mathrm{~m}$ (Fig. 6). Length differences with depth at other stations are summarized in Table 2. Comparisons of the length frequency of larvae sampled by the epibenthic sled with that of the bongo nets indicates that larvae were slightly larger near the bottom (Fig. 7).

\section{Horizontal distribution in the Bay of Fundy}

Sea scallop learvae were present in much of the Bay of Fundy in each of the three sampling periods in 1984 (Fig. 8) and in October of 1985 (Fig. 9). When the mean abundance $\left(\mathrm{nm}^{-2}\right)$ of larvae of all sizes was considered, the Outer Bay and Middle Bay (Nova Scotia side) generally had significantly greater numbers of larvae per $\mathrm{m}^{2}$ than the other areas. November 1984 was the exception with only the New Brunswick side of the Inner Bay showing a significantly lower mean number per $\mathrm{m}^{2}$ (Table 3).

To examine the abundance of late stage larvae only, larvae larger than $230 \mu \mathrm{m}$ were selected. Larvae of this size are pediveligers, with a functional foot and velum. They are capable of metamorphosis to the juvenile stage in the laboratory. All larvae will metamorphose before a size of approximately $300 \mu \mathrm{m}$ is reached (Culliney, 1974; P. Dabinett, Marine Sciences Research Laboratory, Memorial University of Newfoundland, St. John's, pers. comm.). Results of an analysis of variance (Table 4) indicate that the magnitude of the differences was not as great as when all sizes are considered, but the pattern was similar. In October of both years, the Outer Bay and Middle Bay had the greatest mean number per $\mathrm{m}^{2}$ of larvae larger than $230 \mu \mathrm{m}$. The Middle Bay (New Brunswick side) had a high mean number per $\mathrm{m}^{2}$ (compare Tables 3 and 4). Again November 1984 was the exception with no significant differences in number per $\mathrm{m}^{2}$ detected (an analysis of variance could not be completed for September 1984 due to violation of assumptions) (Table 4).

\section{Bay of Fundy length frequency distributions}

In 1984 , larvae ranging in length from 144 to $300 \mu \mathrm{m}$ were sampled by the $120 \mu \mathrm{m}$ mesh nets (Fig. 10). However, since the pump samples were screened on a smaller mesh, and larvae as small as $104 \mu \mathrm{m}$ were retained, these samples, though fewer in number, are more representative of the actual size distribution (Fig. 11). In September, the length frequency of larvae collected at some Outer Bay stations ( 80 and 82 ) differed little from that of an Inner Bay station (111). However, 

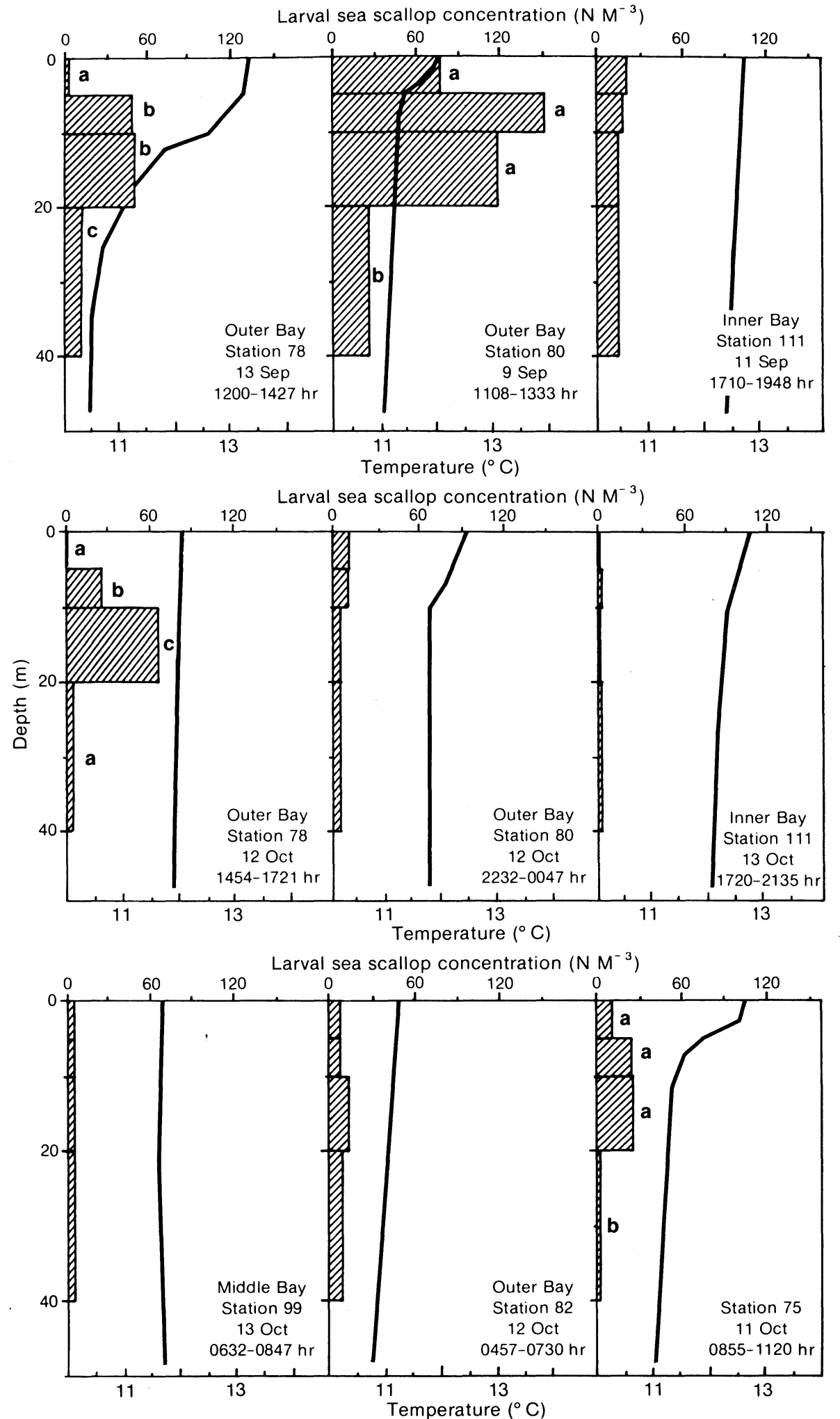

Fig. 4. Larval sea scallop concentration (striped bars) and temperature (solid line) versus depth in September and October 1984. Larval concentrations within each depth interval (0.5 to $5 \mathrm{~m}, 6$ to $10 \mathrm{~m}, 11$ to $20 \mathrm{~m}$, and 21 to $40 \mathrm{~m}$ ), represent the mean of two replicate samples. Depth intervals with different letters opposite were significantly different when compared using Scheffe's procedure. Larval concentrations were $\log _{10}$ transformed prior to the analysis. 


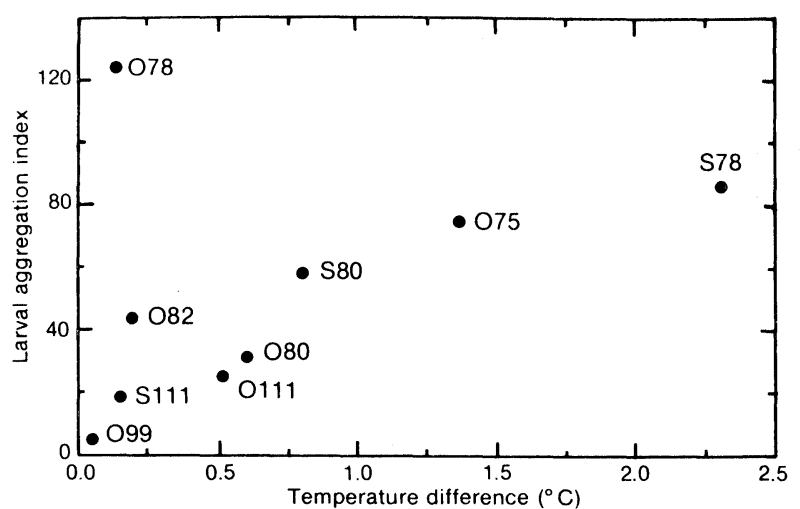

Fig. 5. Larval sea scallop aggregation index versus temperature difference between 0 and $20 \mathrm{~m}$. Aggregation index was the coefficient of variation of the means of the two replicate samples within each of the four depth intervals. Point labels are station identifiers. $(\mathrm{S}=$ September; $\mathrm{O}=$ October.)

another Outer Bay station (78) was dominated by small larvae. In October there was a shift to larger sizes at the Middle and Inner Bay stations (Fig. 12).

During the October 1985 cruise, the whole size range of larvae was sampled using the bongo nets due to the change to smaller mesh. Since many more samples were obtained within each area with the nets in 1985 compared to the pump in 1984, these data provide the best basis for comparison of length frequencies among the different areas (Fig. 13). A shift to larger sizes in the Inner Bay is indicated, particularly on the New Brunswick side.

In 1985, the Scotian Shelf larval concentrations were generally lower than in the Bay of Fundy (Fig. 9). The length frequency distribution of larvae from the Scotian Shelf (Fig. 14) differs from that in the Bay of Fundy in that few larvae larger than $200 \mu \mathrm{m}$ were collected.

To test the hypothesis that a gradient in larval length existed between the inner part of the southwestern Scotian Shelf and the Bay of Fundy due to downstream transport, modal larval length was regressed on station distance to the Outer Bay of
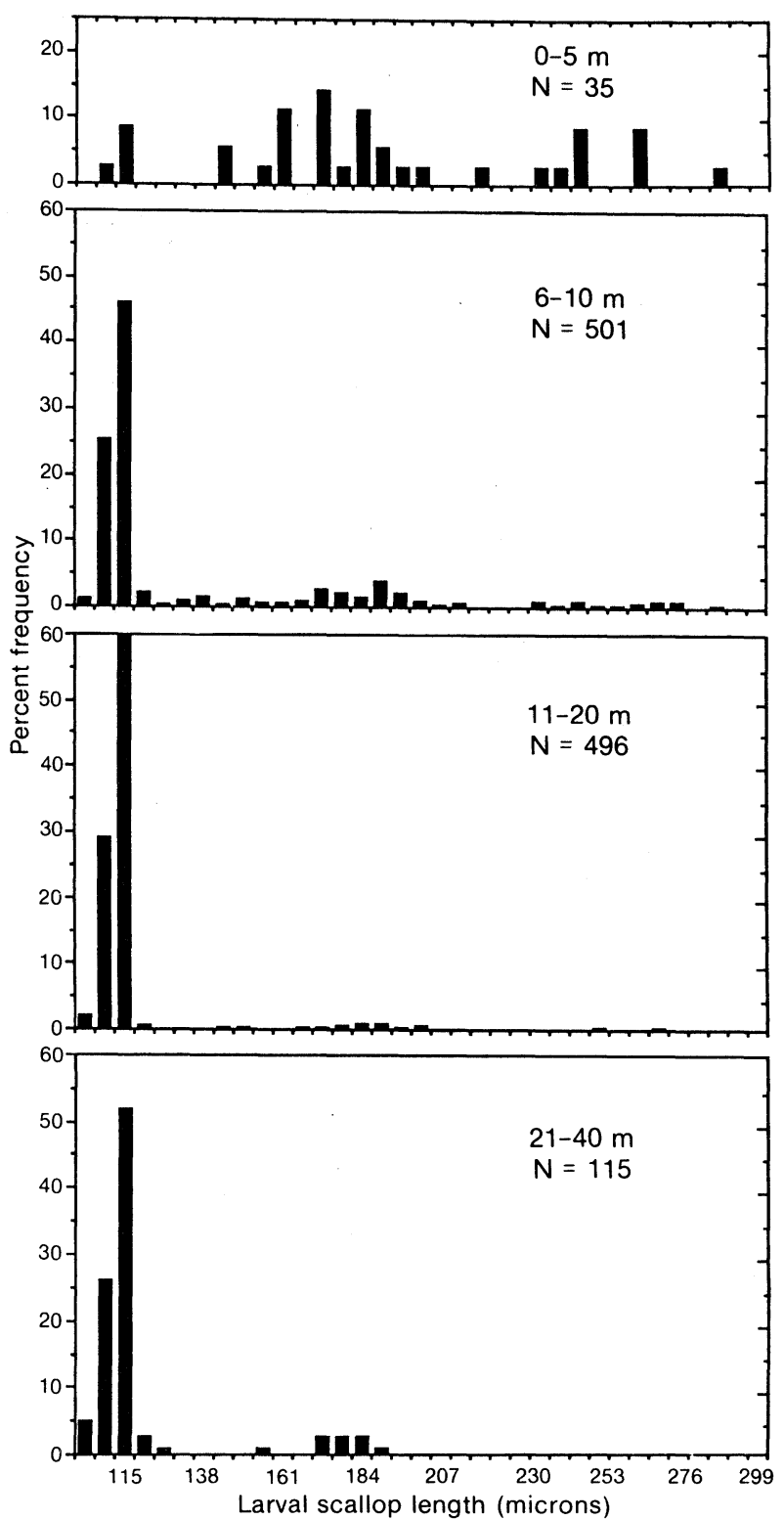

Fig. 6. Length frequency distribution of sea scallop larvae collected at different depths at station 78 on 13 September 1984. Lengths of larvae from the two replicate samples from each depth interval were pooled.

TABLE 2. Mean lengths of sea scallop larvae (in $\mu \mathrm{m}$ ) within different depth intervals in September and October 1984. When comparing within stations (columns) mean lengths with different superscripted letters are significantly different (Mann-Whitney comparisons, $p<.05$ ). Comparisons between depths at any one station were done only if a Kruskal-Wallis analysis of variance by ranks was significant.

\begin{tabular}{|c|c|c|c|c|c|c|c|c|c|}
\hline \multirow{3}{*}{$\begin{array}{l}\text { Depth } \\
\text { (m) }\end{array}$} & \multicolumn{3}{|c|}{ September } & \multicolumn{6}{|c|}{ October } \\
\hline & \multicolumn{3}{|c|}{ Station number (No. of length measurements) } & \multicolumn{6}{|c|}{ Station number (No. of length measurements) } \\
\hline & $78(1,147)$ & $111(600)$ & $80(3,874)$ & $78(1,041)$ & $111(72)$ & $80(290)$ & $82(342)$ & $99(207)$ & $75(655)$ \\
\hline $0-5$ & $189^{a}$ & $154^{\mathrm{a}}$ & 153 & $207^{\mathrm{a}}$ & 203 & 198 & $198^{\mathrm{a}}$ & 187 & 182 \\
\hline $6-10$ & $133^{b}$ & $153^{a}$ & 161 & $201^{a}$ & 200 & 193 & $192^{\mathrm{a}}$ & 184 & 177 \\
\hline $11-20$ & $117^{c}$ & $161^{b}$ & 156 & $178^{b}$ & 213 & 195 & $179^{b}$ & 188 & 174 \\
\hline $21-40$ & $123^{c}$ & $162^{b}$ & 155 & $194^{\mathrm{a}}$ & 227 & 196 & $179^{b}$ & 184 & 174 \\
\hline
\end{tabular}


TABLE 3. Mean number of sea scallop larvae per $\mathrm{m}^{2}$ (all sizes) within different areas of the Bay of Fundy during different seasons in 1984 and 1985. When comparing within cruises (columns) means with different superscripted letters were significantly different $(p<0.05)$ when compared using Scheffe's procedure. Comparisons between means within any one season were done only when a parametric analysis of variance was significant. Prior to analyses the following transformation was made: $y=\log _{10}\left(\mathrm{~nm}^{-2}+1\right)$. The number of stations per area are in parentheses.

\begin{tabular}{lrrrrrr}
\hline \hline & \multicolumn{4}{c}{1984} & & \multicolumn{1}{c}{1985} \\
\cline { 2 - 5 } \cline { 2 - 5 } Area & \multicolumn{1}{c}{ Sep } & \multicolumn{1}{c}{ Oct } & Nov & & Oct \\
\hline Outer Bay & $629.1(10)^{\mathrm{a}}$ & $239.0(16)^{\mathrm{a}}$ & $18.9(17)^{\mathrm{ab}}$ & & $915.0(22)^{\mathrm{a}}$ \\
Middle Bay, Nova Scotia & $494.2(4)^{\mathrm{a}}$ & $146.9(4)^{\mathrm{a}}$ & $65.2(3)^{\mathrm{a}}$ & & $355.4(5)^{\mathrm{ab}}$ \\
Inner Bay, Nova Scotia & $11.0(4)^{\mathrm{b}}$ & $18.7(4)^{\mathrm{b}}$ & $10.8(5)^{\mathrm{ab}}$ & & $18.6(7)^{\mathrm{c}}$ \\
Inner Bay, New Brunswick & - & $13.1(2)^{\mathrm{b}}$ & $1.2(6)^{\mathrm{c}}$ & & $12.9(5)^{\mathrm{c}}$ \\
Middle Bay, New Brunswick & - & $100.3(4)^{\mathrm{a}}$ & $8.5(5)^{\mathrm{bc}}$ & & $150.6(6)^{\mathrm{b}}$ \\
\hline
\end{tabular}

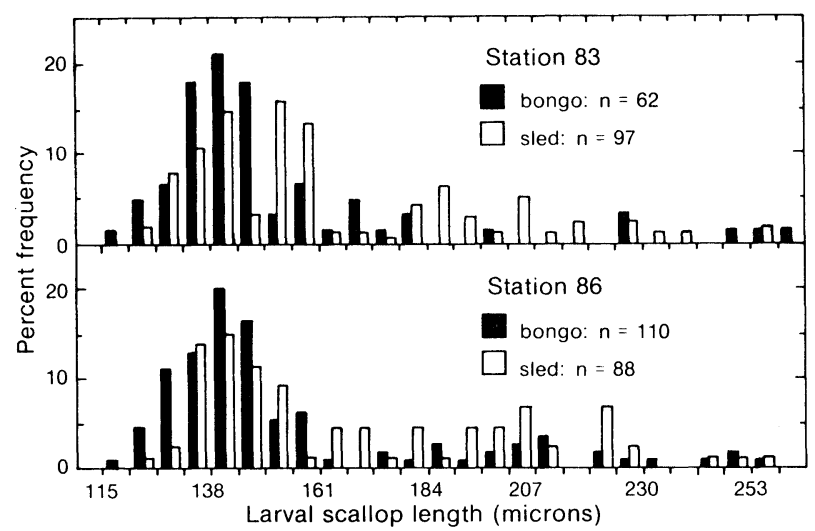

Fig. 7. Length frequency distribution of sea scallop larvae collected by epibenthic sled versus bongo net. Lengths of larvae from both samples collected by the epibenthic sled (approximately 50 and $130 \mathrm{~cm}$ above the sea bed) were pooled.
Fundy (outer most boundary line in Fig. 3). The analysis was limited to those stations where at least 10 length measurements were available (station S7 to S9, S19 to S26, S42 to S44, 22 to 24,84 and 85 , Fig. 3). The regression was not significant (Fig. 15).

\section{Discussion}

\section{Vertical distribution}

The presence of sea scallop larvae throughout the water column does not agree with what has been assumed in the past (e.g. Posgay 1979). Larvae were never most abundant in the near surface layer (upper $10 \mathrm{~m}$ ), and were distributed equally over the upper $40 \mathrm{~m}$ in well mixed areas. Other investigators, concerned with total bivalve larvae rather than single species, have

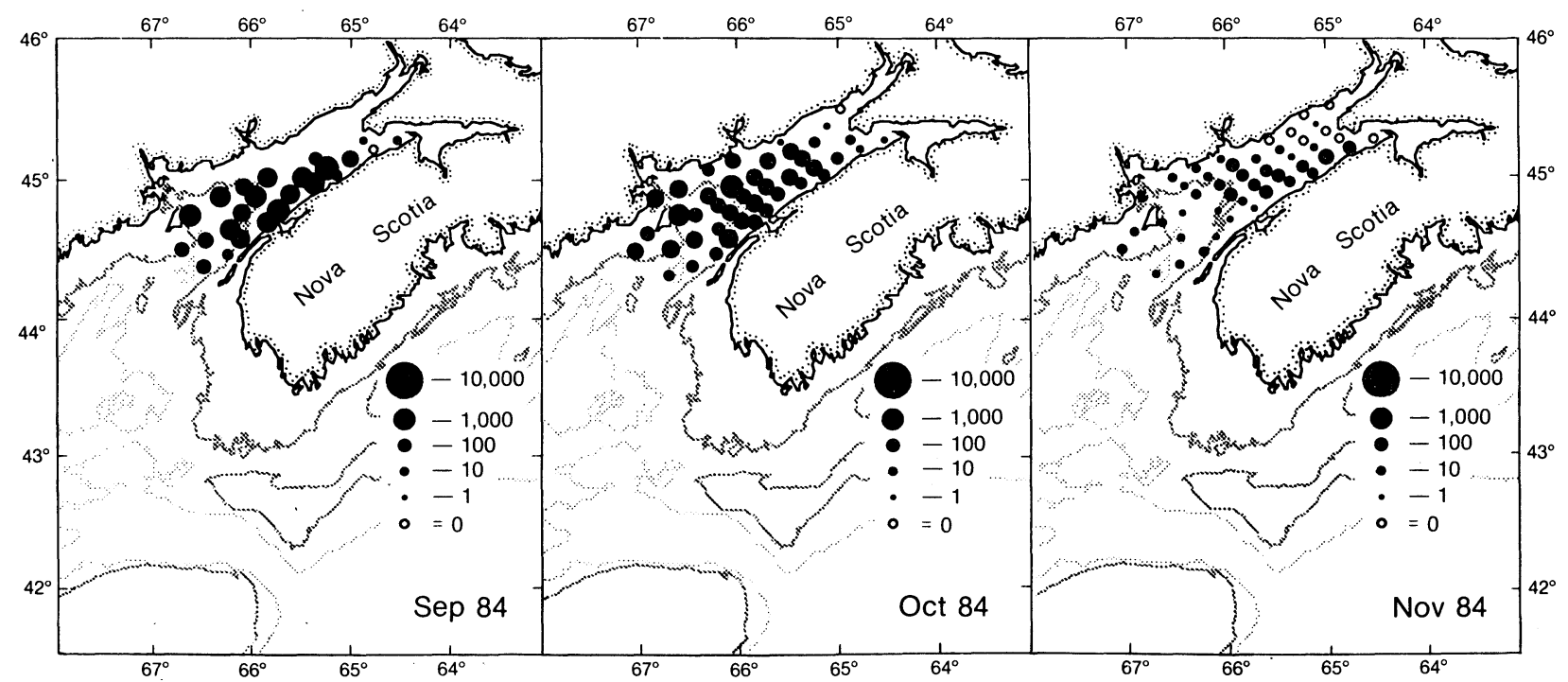

Fig. 8. Number per $\mathrm{m}^{2}$ of sea scallop larvae collected by bongo net during 1984. Note that scallop larvae less than 140 microns were unsampled (mesh size $=120$ microns). Size of circles in the key corresponds to the discrete values indicated. Plotted circle sizes are continuous. 


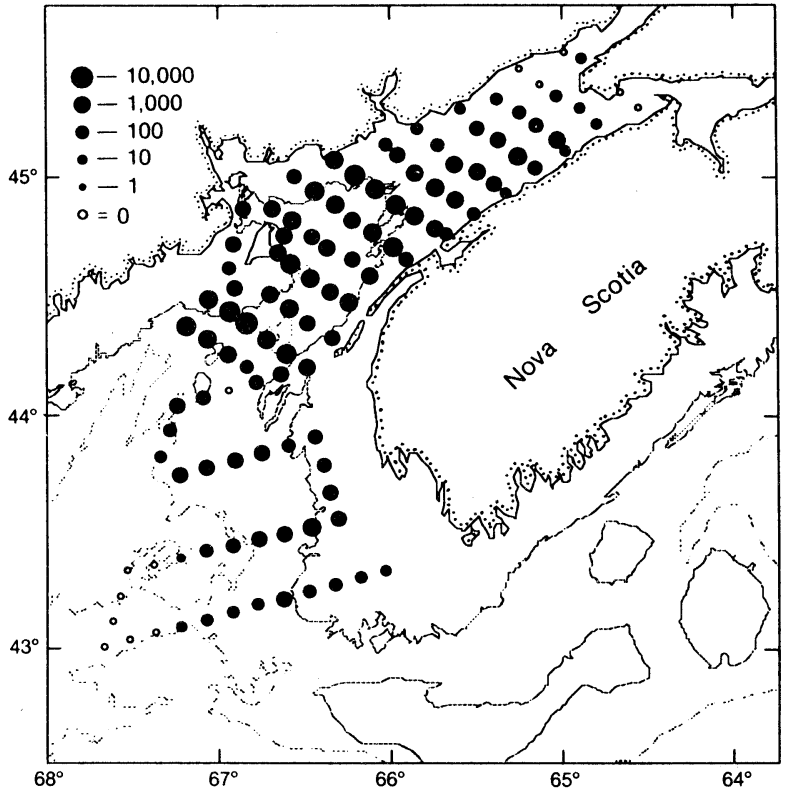

Fig. 9. Number per $\mathrm{m}^{2}$ of sea scallop larvae collected by bongo net during 1985. Note that the total size range of scallop larvae was sampled (mesh size $=85$ microns). (Scale differs from Fig. 8 because more larvae were caught due to change to smaller mesh size.)

TABLE 4. Mean number of large sea scallop larvae $(>230 \mu \mathrm{m})$ per $\mathrm{m}^{2}$ within different areas of the Bay of Fundy during different seasons in 1984 and 1985. For further description of table, and the number of stations per area, refer to Table 3. (Note that no analysis was possible for September 1984 due to a violation of the assumption of homoscedasticity.

\begin{tabular}{lrrrr}
\hline \hline & \multicolumn{3}{c}{1984} & \\
\cline { 2 - 4 } & Sep & \multicolumn{1}{c}{ Oct } & Nov & Oct \\
\hline Outea & 97.2 & $40.6^{\mathrm{a}}$ & 4.2 & $35.7^{\mathrm{a}}$ \\
Middle Bay, Nova Scotia & 91.6 & $6.5^{\mathrm{b}}$ & 11.6 & $8.2^{\mathrm{b}}$ \\
Inner Bay, Nova Scotia & 2.2 & $2.5^{\mathrm{b}}$ & 3.0 & $3.8^{\mathrm{b}}$ \\
Inner Bay, New Brunswick & - & $2.9^{\mathrm{b}}$ & 1.2 & $3.9^{\mathrm{b}}$ \\
Middle Bay, New Brunswick & - & $38.5^{\mathrm{a}}$ & 2.0 & $17.2^{\mathrm{a}}$ \\
\hline
\end{tabular}

found larvae to be most abundant below $10 \mathrm{~m}$ on the New England Shelf (Mann, 1985), in the Irish Sea (Scrope-Howe and Jones, 1986) and in the waters off Plymouth (Southward and Barrett, 1983). Because larval scallops (and other bivalves) are not confined to narrow surface layers, changes in current speed with depth must be considered if models of larval scallop dispersal are to be constructed. The vertical aggregation of sea scallop larvae, observed in areas with a thermocline, was also observed by Scrope-Howe and Jones (1986) for total bivalve larvae. Although they also observed some vertical aggregation in isothermal areas, the extent of aggregation was much greater in areas with a therrnocline.

Active aggregation by sea scallop larvae in the area of the thermocline (as opposed to physical accumulation there by currents) is a distinct possibility given that

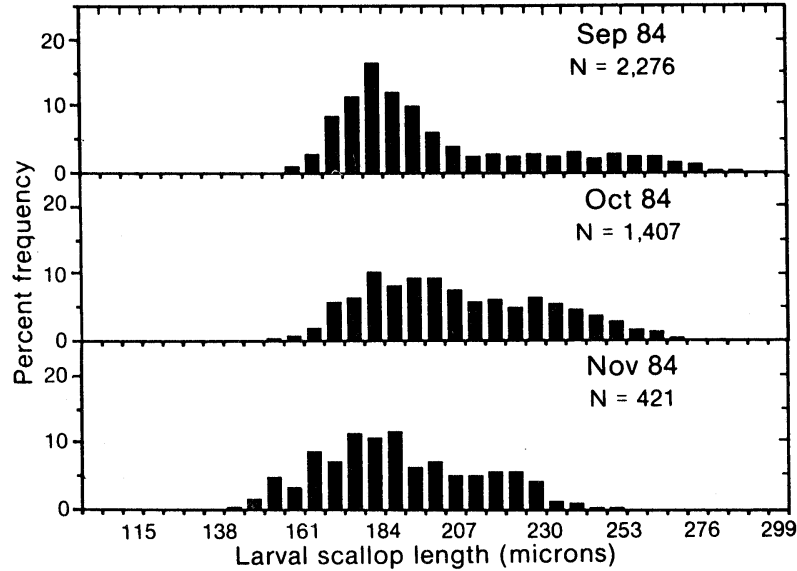

Fig. 10. Length frequency distribution of sea scallop larvae collected by bongo nets during 1984. All length measurements from stations sampled in the Outer, Middle and Inner Bay areas were utilized. The number of length measurements from any one station was weighted according to the number per $\mathrm{m}^{2}$ at that station.

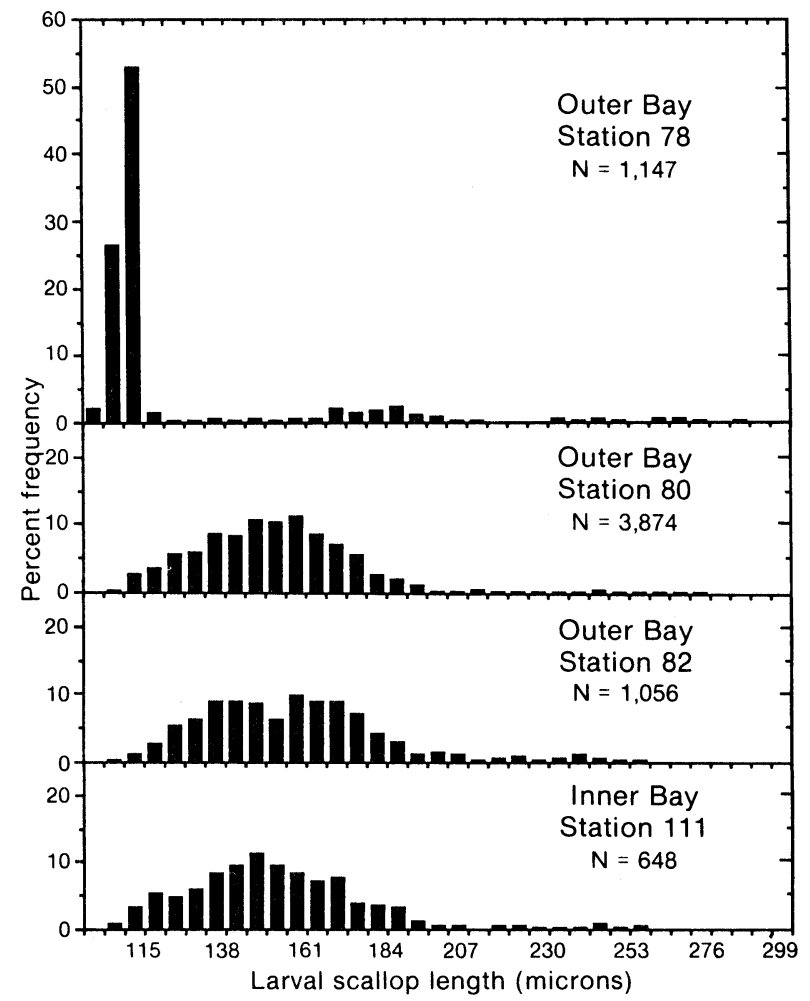

Fig. 11. Length frequency distribution of sea scallop larvae collected by pump during September 1984. Length measurements from all depths are included.

bivalve larvae can occupy different depths during the day compared to the night. It is not possible to draw conclusions as to the occurrence of diurnal vertical migration from the present study because vertical sampling was not carried out over $24 \mathrm{hr}$ at any one station. Evidence from other work (Tremblay and Sinclair, unpublished; Scrope-Howe and Jones, 1986) indicates 


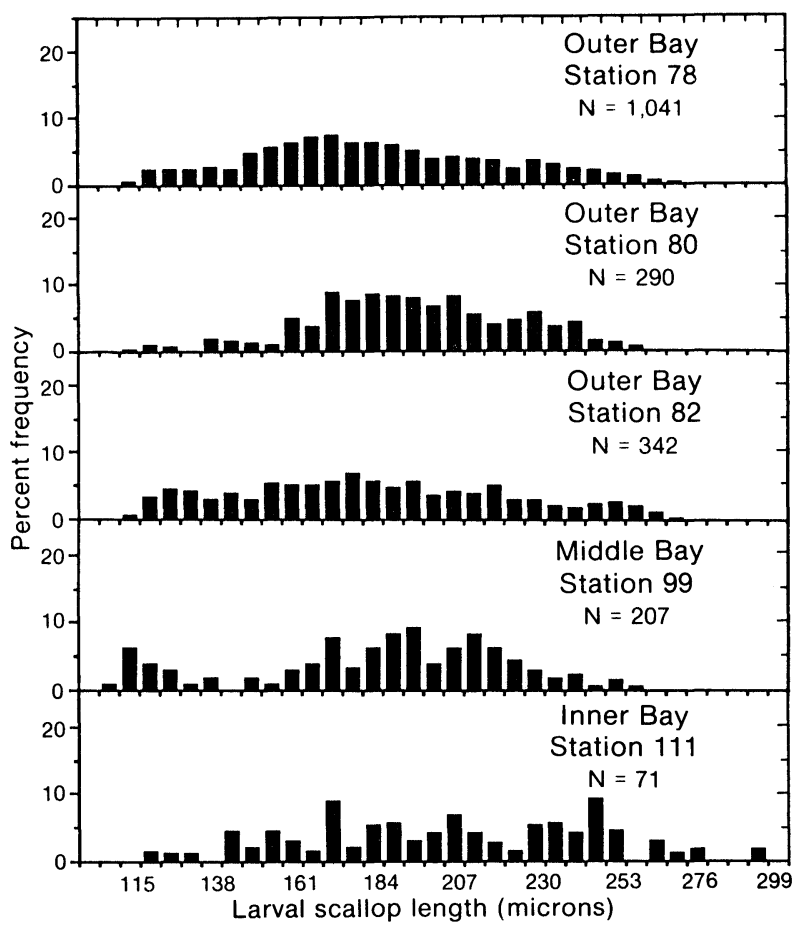

Fig. 12. Length frequency distribution of sea scallop larvae collected by pump during October 1984. Length measurements from all depths are included.

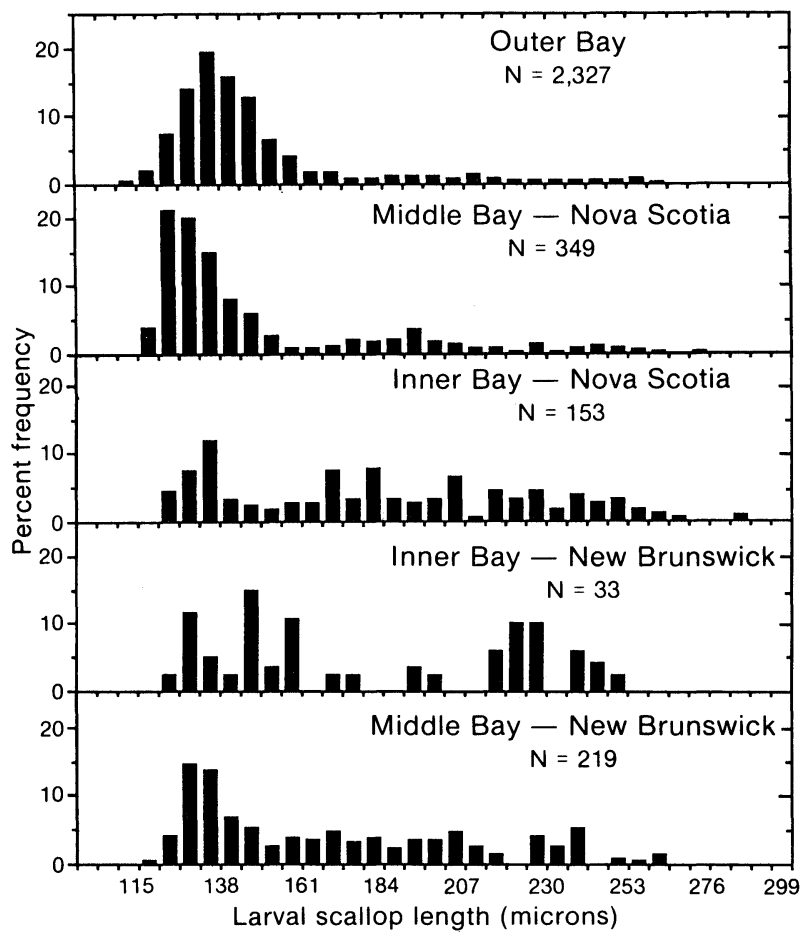

Fig. 13. Length frequency distribution of sea scallop larvae collected by bongo net in the Bay of Fundy in 1985. Length measurements from all stations sampled within stated areas were utilized.

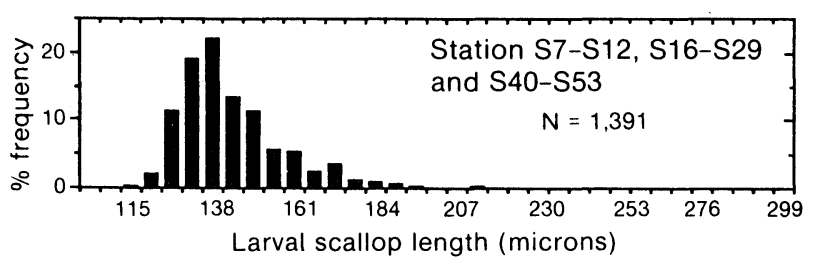

Fig. 14. Length frequency distribution of sea scallop larvae collected by bongo net on the Scotian Shelf in 1985. Station locations are indicated on Fig. 3.

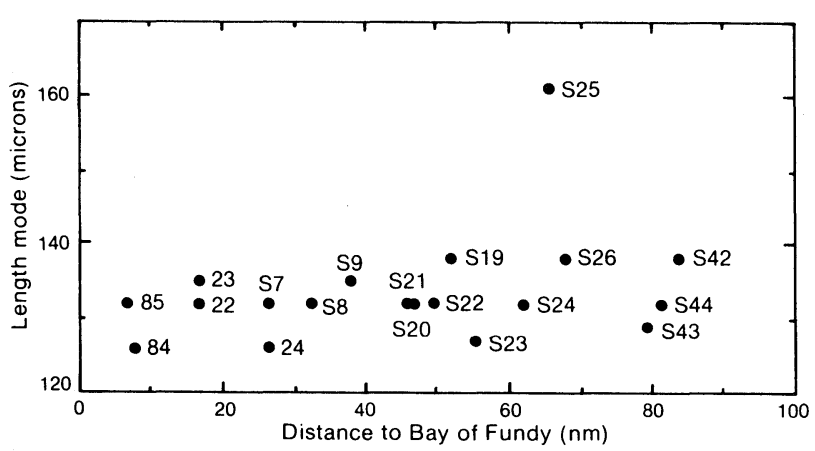

Fig. 15. Larval sea scallop length mode versus station distance (nautical miles) to the outer boundary of the Outer Bay area depicted in Fig. 3. Point labels are station designations (see Fig. 3.) A regression of length mode on station distance was not significant $(p>0.8)$.

bivalve larvae have the ability to undertake small amplitude diurnal vertical migrations in coastal areas, moving to shallower water at night.

At this time it is only possible to speculate as to why the larvae aggregated in the area of the thermocline. Salinity was not measured and therefore it cannot be determined if the larvae were aggregating in areas of the water column where density was rapidly changing. It is possible that the larvae were concentrating in areas of high food availability associated with the base of the thermocline. Scrope-Howe and Jones (1986) observed that bivalve larvae moved into the chlorophyll maximum during the night. The actual food available to sea scallop larvae (smaller phytoplankton and perhaps particulate organic matter) must be quantified before any conclusions regarding the reasons for vertical aggregation in areas with a thermocline are to be drawn.

Station 78 in October (Fig. 4 and 5) was an exception to the rule of greater vertical aggregation of larvae at stations with a thermocline. It is possible that a pycnocline due to salinity stratification was present at this location, and that the larvae were responding to a density difference rather than a temperature difference. Bailey et al. (1954) summarized mean monthly temperatures and salinities in the surface $(0-25 \mathrm{~m})$, intermediate $(25-75 \mathrm{~m})$ and bottom $(75-90 \mathrm{~m})$ layers at a station in the Outer Bay of Fundy. In October the mean salinity 
at the surface was $32.50 \%$; that in the intermediate layer approximately $32.62 \%$. Temperatures in the two layers were $10.8^{\circ}$ and $10.6^{\circ} \mathrm{C}$, respectively. Calculations of sigma-t values (24.89 in the surface layer and 25.02 in the intermediate) indicate that under these conditions, the change in salinity contributes most to the difference in sigma-t.

Our finding of vertical stratification by size at approximately half the pump stations (Table 2) is puzzling. Larger larvae were close to the surface at most of these stations but except for station 78 in September 1984, the differences in mean length with depth were not great. It should be noted here that it was a sunny, calm day when station 78 was sampled, perhaps allowing larval behavior to overcome upwelling and downwelling currents which may be greater on rougher days.

The slightly larger size of larvae collected close to the bottom by the epibenthic sled (Fig. 7) may indicate that larger larvae occupy a broader range of depths, which is consistent with increased swimming ability with size. Alternatively, the different sampling gears used (sled versus bongo) may account for the relatively small difference in length frequency which was observed. However, only a small fraction of the larvae close to the bottom had reached a size where metamorphosis and settlement was possible $(>230 \mu \mathrm{m})$. Thus at these stations at least, the area 1 to $2 \mathrm{~m}$ off the bottom was not dominated by large larvae searching for the appropriate settlement substrate.

\section{Horizontal distribution of larvae in relation to circulation}

The results of the present study are equivocal in regard to the question of transport of larvae within the Bay of Fundy. The results indicate a situation somewhere between no downstream transport (retention in the Outer and Middle Bay areas) and extensive downstream losses, with larvae accumulating in the Inner Bay area. Qualitatively, it can be stated that most larvae are found in the Outer Bay during the months when their abundance is greatest (September and October) and downstream losses are not a dominant feature in the distribution of larval sea scallops in the Bay of Fundy.

The distribution of spawning biomass (from fishery catch statistics) suggests most larvae were spawned in the Outer and Middle Bay areas, with only $2-3 \%$ originating in the Inner Bay (Table 1). Statistical comparison of the mean number of larvae per $\mathrm{m}^{2}$ (all sizes and larvae $>230 \mu \mathrm{m}$ ) within the different areas indicates that in most seasons, the Inner Bay (either one or both sides) had the lowest abundance. Low numbers of larvae in the Inner Bay would be expected if larval transport to this area was minimal. Although
November 1984 was an important exception, it was also the season when larvae were least abundant overall.

Comparison of length frequency distributions indicate that in three of four cruises (including October 1985 when the larval length data were most complete), the Inner Bay had larger larvae than the Outer Bay, which is consistent with larval transport to the Inner Bay. Alternative explanations for the observed patterns in larval length are earlier spawning or increased larval survival in the Inner Bay. There is little information on spawning time in the Inner Bay, since most research has been directed at the Outer and Middle Bay areas where sea scallops are most abundant. Given the higher temperatures and shallower depths in the Inner Bay, earlier spawning cannot be ruled out. Increased survival in the Inner Bay would seem unlikely given the increased turbidity and lower levels of primary production in this area (Prouse, 1983).

Differences between the Nova Scotia and New Brunswick sides of the Bay of Fundy with respect to mean abundance of large larvae (Table 4), and of overall length frequency (Fig. 13) may be a reflection of the counterclockwise circulation in the Bay of Fundy. If some larvae are transported around the Bay, a buildup of larger larvae on the New Brunswick side would be expected.

Although changes in length frequency and abundance provide evidence for some larval transport within the Bay of Fundy during 1984 and 1985, no evidence exists for larval transport along the inner Scotian Shelf into the Bay of Fundy. The larval length mode on the inner Scotian Shelf did not increase along the expected path of transport into the Bay of Fundy (Fig. 15). Of course circulation on the Scotian Shelf is almost certainly not as simple as indicated here, and if scallop spawning times differ greatly over the area, the situation becomes considerably more complex.

This study allows only a few statements to be made about the source and dispersal of sea scallop larvae in the Bay of Fundy. The sampling scheme upon which the study is based (monthly semi-synoptic cruises), and our present understanding of factors such as larval growth and mortality, areal differences in spawning time, and details of horizontal and vertical current structure, preclude any definitive conclusions. Nevertheless the study suggests that the major source of recruitment to the Bay of Fundy scallop aggregations originates in the Bay of Fundy. Larvae of all sizes were found in the Outer Bay, where most potential spawners are located, and larval input from the Scotian Shelf could not be demonstrated. To what extent larvae are 'lost' from the Bay of Fundy cannot be assessed from the present study. There were high larval concentrations in the approaches to the Bay of Fundy during 1985 
but they could have originated there or within the Bay of Fundy. Understanding of larval scallop origin and transport will increase only with studies which integrate biology with physical oceanography.

\section{Acknowledgements}

We thank the captains and crews of the Lady Hammond, E. E. Prince, and John Eric III for enabling us to carry out our sampling program and $\mathrm{D}$. Wildish for loaning us his epibenthic sled. We also thank D. Meade and $U$. Earanky for processing many of the larval scallop samples and $\mathrm{G}$. Black for assisting in the computer mapping. The comments of G. E. Ennis and two anonymous reviewers were most helpful and greatly appreciated by the authors.

\section{References}

BAILEY, W. B., D. G. MacGREGOR, and H. B. HACHEY. 1954. Annual variations of temperature and salinity in the Bay of Fundy. J. Fish. Res Board Can., 11: 32-47.

BE, A. W. H., N. D. CROCE, A. BOUDILLON, A de DECKER, B. KIMOR, E. HAGMEIER, and B. BOGOROV. 1968. Smaller mesoplankton. Report of working party no. 2. p. 153-159. In: Zooplankton Sampling, D. J. Tranter (ed.). UNESCO Monographs on Oceanographic Methodology 2. Geneva Switzerland. $174 \mathrm{p}$.

BOURNE, N. 1964. Scallops and the offshore fisheries of the Maritimes. Bull. Fish. Res. Board Can., 145: 60 p.

BRUNEL, P., M. BESNER, D. MESSIER, L. POIRIER, D. GRANGER, and M. WEINSTEIN. 1978. The MacerGIROQ suprabenthic sled: an improved device for quantitative two-level sampling of the small swimming fauna near the bottom. Int. Rev. Gesamt. Hydrobiol., 63: 815-829.

CADDY, J. F. 1979. Long-term trends and evidence for production cycles in the Bay of Fundy scallop fishery. ICES Rapp. Proc.-Verb., 175: 97-108.

COUTURIER, C. Y. MS 1986. Aspects of reproduction and larval production in Placopecten magellanicus held in a semi-natural environment. M.Sc Thesis, Dalhousie Univ., Halifax, N. S., 108 p.

CULLINEY, J. L. 1974. Larval development of the giant scallop Placopecten magellanicus (Gmelin). Biol. Bull., 147: 321-332.

DICKIE, L. M. 1955. Fluctuations in abundance of the giant sea scallop, Placopecten magellanicus (Gmelin) in the Digby area of the Bay of Fundy. J. Fish. Res. Board Can., 12: 797-857.
GODIN, G. 1968. The 1965 current survey of the Bay of Fundy - A new analysis of the data and interpretation of the results. Manuscript Rep. Ser. Mar. Sci. Dir. (Can.), No. 8.

GREENBERG, D. A. 1983. Modeling the mean barotropic circulation in the Bay of Fundy and the Gulf of Maine. J. Phys. Oceanogr., 13: 886-904.

LAUZIER, L. M. 1967. Bottom residual drift on the continental shelf area of the Canadian Atlantic coast. J. Fish. Res. Board Can., 24: 1845-1859.

MANN, R. 1985. Seasonal changes in the depth-distribution of bivalve larvae on the southern New England shelf. J. Shellfish Res., 5: 57-64.

POSGAY, P. A. 1979. Population assessment of the Georges Bank sea scallop stocks. ICES Rapp. Proc.-Verb., 175: 109-113.

PROUSE, N. J.1983. Primary production measurements in the Bay of Fundy from March 1979 to November 1980. Can. Tech. Rep. Fish. Aquat. Sci., 1167: 86 p.

ROBERT, G., M. A. E. BUTLER-CONNOLY, and M. J. LUNDY. 1986. Bay of Fundy scallop stocks assessment, 1985. Can. Atl. Fish. Sci. Adv. Committee Res. Doc., No. 40, 25 p.

ROBERT, G. and M. J. LUNDY. MS 1985. Reproductive aspects of the deep sea scallop (Placopecten magellanicus) in the Bay of Fundy near Digby, Nova Scotia. Paper presented at the 5th Pectinid Workshop, La Coruna, Spain, 6-10 May 1985.

SAVAGE, N. B. 1980. Monitoring of bivalve larvae continues off the New Hampshire coast. Coast. Oceanogr. Climatol. News, 2: 44-45.

SERCHUK, F. M., P. W. WOOD, J. A. POSGAY, and B. E. BROWN. 1979. Assessment and status of sea scallop (Placopecten magellanicus) populations of the northeast coast of the United States. Proc. Natl. Shellfish. Assoc., 69: 161-191.

SCROPE-HOWE, S., and D. A. JONES. 1986. The vertical distribution of zooplankton in the western Irish Sea. Estuar. Coast. Shelf Sci., 22: 785-802.

SINCLAIR, M., R. K. MOHN, G. ROBERT and D. L. RODDICK. 1985. Considerations for the effective management of Atlantic scallops. Can. Tech. Rep. Fish. Aquat. Sci., 1382: $113 \mathrm{p}$.

SMITH, P. C. 1983. The mean and seasonal circulation off southwest Nova Scotia. J. Phys. Oceanogr., 13: 1034-1054.

SOUTHWARD, A. J., and R. L. BARRETT. 1983. Observations on the vertical distribution of zooplankton, including post-larval teleosts, off Plymouth in the presence of a thermocline and a chlorophyll-dense layer. J. Plankton Res., 5: 599-618.

TEE, K. T. 1977. Tide-induced residual current, a 2D nonlinear tidal model. J. Mar. Res., 34: 603-628.

TREMBLAY, M. J., L. D. MEADE, and G. V. HURLEY. 1987. Identification of planktonic sea scallop larvae (Placopecten magellanicus) (Gmelin). Can. J. Fish. Aquat. Sci., 44: 1361-1366. 
